\title{
GENETIC DIVERSITY OF INTRODUCED (POMACEA CANALICULATA) \\ AND NATIVE (PILA) APPLE SNAILS IN THAILAND REVEALED BY RANDOMLY AMPLIFIED POLYMORPHIC DNA (RAPD) ANALYSIS
}

\author{
B. Thaewnon-ngiw \\ Program of Bioscience, Graduate School of Kasetsart University, \\ Bangkok 10900, Thailand

\section{S. Klinbunga*} \\ Marine Biotechnology Research Unit, National Center for \\ Genetic Engineering and Biotechnology (BIOTEC), \\ National Science and Technology Development Agency (NSTDA), \\ 113 Paholyothin Rd., Klong 1, Klong Luang, Pathumthani 12120, Thailand
}

\section{K. Phanwichien}

Department of Zoology, Faculty of Science, Kasetsart University, Bangkok 10900, Thailand

\section{N. Sangduen}

Department of Genetics, Faculty of Science, Kasetsart University, Bangkok 10900, Thailand

\section{N. Lauhachinda}

Department of General Science Faculty of Science, Kasetsart University, Bangkok 10900, Thailand

\section{P. Menasveta}

Department of Marine Science, Faculty of Science, Chulalongkorn University, Bangkok 10330, Thailand

Corresponding author e-mail: sirawut@biotec.or.th 


\begin{abstract}
Genetic diversity of the introduced golden apple snail, Pomacea canaliculata (Lamarck, 1822) and four native apple snails; Pila ampullacea (Linneaus, 1758), P. angelica (Annandale, 1920), $P$. pesmei (Morelet, 1889) and $P$. polita (Deshayes, 1830) in Thailand were studied by RAPD analysis. Two hundred and two polymorphic fragments (180-1500 bp in length) were generated across overall investigated samples $(N=254)$ using three informative primers (OPA07, OPB10 and UBC122). The percentages of polymorphic bands were $98.86 \%, 94.56 \%, 90.91 \%, 96.94 \%$ and $95.51 \%$ for Pomacea canaliculata, P. ampullacea, P. angelica, P. pesmei and P. polita, respectively. This indicated high genetic polymorphism of these taxa. A neighbor-joining tree between pairs of geographic samples within Pomacea canaliculata suggested a lack of phylogeography in this species. Moreover, candidate species-specific RAPD markers (pKUSCARPILA-F/R) found in Pomacea canaliculata (340 bp, OPB10), P. ampullcea (640 bp, OPA07), P. angelica (380 bp, UBC122) and Pila snails (430 bp, OPA07) were cloned and sequenced. Locus-specific primers were designed and tested against the target and nontarget species. A 259 bp SCAR marker was found in $95.0 \%$ of Pila apple snails $(N=163)$ but not in Pomacea canaliculata $(N=30)$. Therefore, this SCAR marker could be used in coupling with a Pomacea canaliculata-specific RAPD marker to unambiguously differentiate the introduced and native apple snails in Thailand.
\end{abstract}

Keywords : Apple snails, Pomacea, Pila, RAPD-PCR, Genetic diversity

\title{
1. INTRODUCTION
}

The golden apple snail, Pomacea canaliculata (Lamarck, 1822) is found in the new world; South America, Central America, the West Indies and the Southern USA (Pain 1972). It was illegally introduced into Thailand by the fish trade for cleaning fish aquaria because of its ability to consume several kinds of aquatic plants and algae. The golden apple snail was first discovered naturally in Thailand in 1984 (Keawjam and Upatham 1990). Owing to its short period of time to reach maturation stages (2-3 months) and the potential to lay large amounts of eggs, the number of Pomacea canaliculata consistently increases affecting ecological impact of the freshwater communities in Thailand.

The golden apple snail exhibits variability of shell colors and banding patterns ranged from golden yellow, olive yellow to dark olive with different numbers of small and large bands. Using shell morphology, male reproductive organ anatomy and allozymes, Keawjam and Upatham (1990) classified the golden apple snails in Thailand into 3 different species including Pomacea canaliculata, Pomacea insularum and Pomacea sp..

Apple snails indigenous to Thailand were taxonomically recognized as members of the genus Pila. Brandt (1974) classified native apple snails in Thailand to P. ampullacea, P. scutata, P. gracilis, $P$. pesmei and $P$. polita based on shell characteristics, color and sculpture and geographic distributions.

Keawjam (1986) revised a taxonomic identification key of indigenous apple snails in Thailand and morphologically recognized these species as $P$. ampullacea, $P$. angelica, $P$. gracilis, $P$. 
pesmei and $P$. polita. While $P$. angelica was further differentiated from $P$. pesmei, $P$. scutata was taxonomically identified as a non-banded form of $P$. gracilis. Among these species, only $P$. polita are easily differentiated morphologically whereas other four species exhibit taxonomic difficulties and can be misidentified. For instance, $P$. gracilis can be misidentified as the small form of $P$. pesmei and $P$. angelica can be misidentified as the large form of $P$. pesmei. Apparently, P. ampullacea, P. pesmei and P. polita are sympatrically distributed in the north, northeast and central region whereas $P$. angelica and $P$. gracilis are restrictively found in peninsular Thailand.

Severe decreasing of Pila snails may have resulted from ecological competition with Pomacea canaliculata (Lauhachinda et al., 1988). Serious destructive damages of rice crops by the golden apple snail have been reported since 1996. It is regarded as the most important pest for rice crops in Thailand at present (Janyapeth and Archawakom, 1999).

Classification of Pila and Pomacea snails has been carried out based principally on morphological characters. However, the external characteristics (e.g. shell morphology) are influenced by a variety of habitats and environmental conditions (Keawjam, 1986 and 1987). Accordingly, two sympatric species may be morphologically similar and misidentified as a single species. On the other hand, allopatric populations inhabiting different habitats may show ecomorphological variation and have questionable species status.

The basic information on numbers of species and/or populations in a particular area is of importance for conservation programs (Carvalho and Hauser, 1994). Knowledge on genetic variation levels of apple snails in Thailand is, therefore, important for the construction of appropriate management schemes of these species. However, information about inter- and intraspecific genetic diversity of Pila and Pomacea snails in Thailand is not available at present.

RAPD-PCR is a conceptually simple technique for examination of genetic diversity of organisms (Williams et al., 1990; Welsh and McClelland, 1990). Typically, a short oligonucleotide primer (e.g. 10-12 mer) with the $\mathrm{G}+\mathrm{C}$ content $>50 \%$ is used therefore, prior knowledge of the genome under investigation is not required. RAPD analysis essentially scans part of the genome containing priming sites close to one another that are located in an inverted orientation. Polymorphism is treated in a dominant fashion (Williams et al., 1990; Weising et al., 1995). RAPD analysis considerably requires less tedious and time-consuming than other molecular genetic techniques (e.g. restriction fragment length polymorphism, RFLP; single-stranded conformation polymorphism, SSCP and amplified fragment length polymorphism, AFLP) based on fragment polymorphism.

The objectives of this study were to determine genetic diversity of the introduced (Pomacea canaliculata) and native apple snails ( $P$. ampullacea, $P$. angelica, $P$. pesmei and $P$. polita) in Thailand and to identify molecular genetic markers to assist taxonomic identification of Pila and Pomacea canaliculata apple snails using RAPD analysis. Candidate genus- and/or speciesspecific RAPD markers were converted to sequence-characterized amplified region (SCAR) markers through cloning and sequencing. A Pila-specific SCAR marker was successfully developed. 


\section{MATERIALS AND METHODS}

\section{Sampling}

Two hundred and fifty four individuals of apple snails constituting of the introduced golden apple snail, Pomacea canaliculata $(N=136)$ and local apple snails, $P$. ampullacea $(N=21)$, $P$. polita $(N=25), P$. pesmei $(N=47)$ and $P$. angelica $(N=25)$ were collected from geographically different locations in Thailand (Fig. 1 and Table 1). Taxonomic identification of apple snails was carried out according to Brandt (1974), Keawjam (1986) and Keawjam and Upatham (1990).

Figure 1 : Map of Thailand indicating sample collection sites of the introduced (Pomacea canaliculata) and native apple snails ( $P$. ampullacea, P. polita, P. pesmei and $P$. angelica) used this study. Dots represent geographic locations from which at least one species were sampling. Detailed information and abbreviations of sample sites are shown in Table 1.

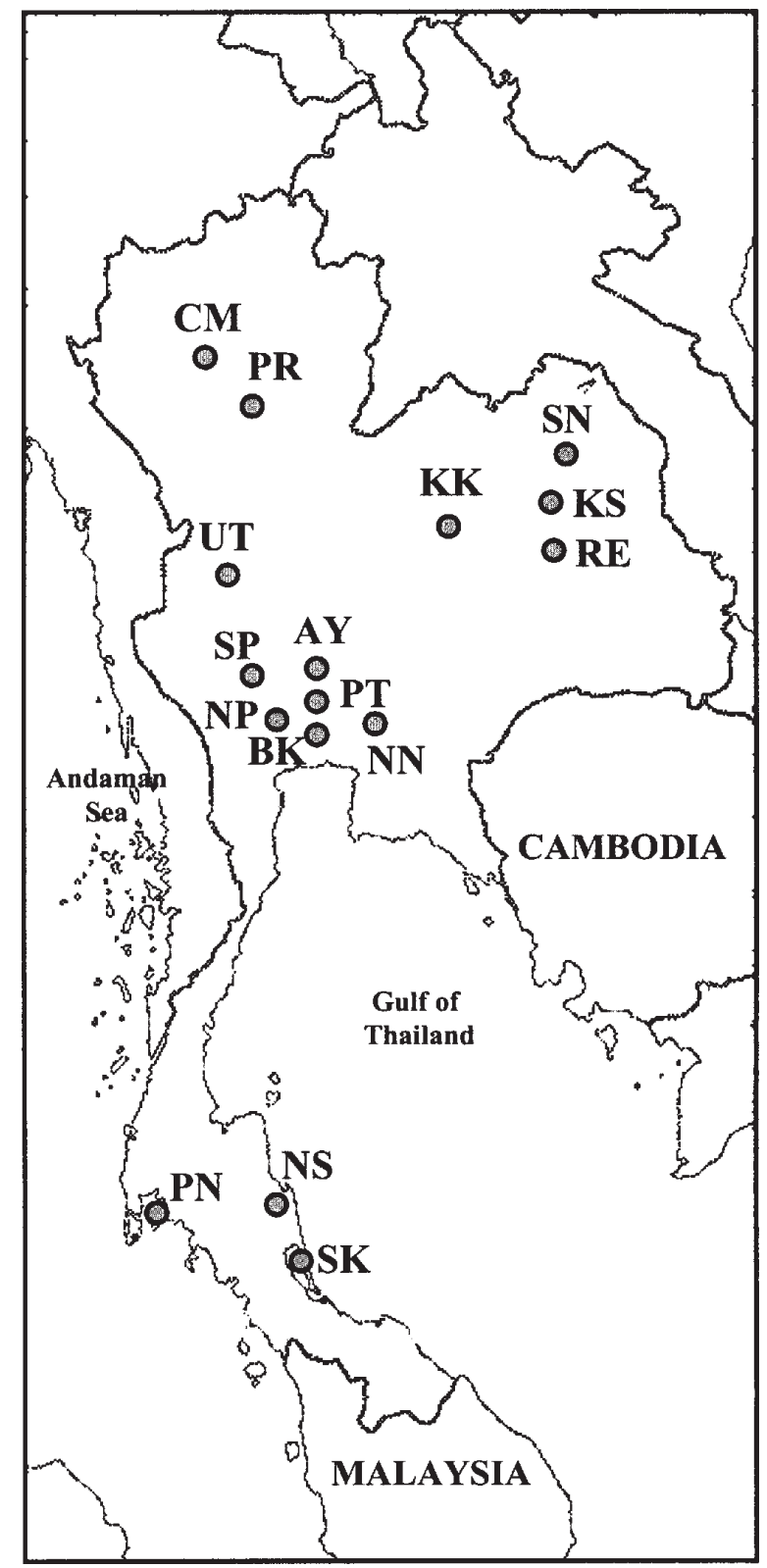


Table 1: Sample collection sites and sample sizes of apple snails used in this study

\begin{tabular}{|c|c|c|c|}
\hline Species & Geographic origin & Abbreviation & $\begin{array}{l}\text { Sample size } \\
(N)\end{array}$ \\
\hline \multirow[t]{14}{*}{ Pomacea canaliculata } & Chiangmai & $\mathrm{PcCMN}$ & 10 \\
\hline & Phrae & PcPRN & 8 \\
\hline & Khonkhen & PcKKNE & 8 \\
\hline & Sakhonnakhon & PcSNNE & 10 \\
\hline & Taling Chun & PcTCBK & 3 \\
\hline & Kasetsart University & PcKUBK & 9 \\
\hline & Nakhonnayok & $\mathrm{PcNNC}$ & 4 \\
\hline & Nakhonpathom & PcNPC & 11 \\
\hline & Suphanburi & $\mathrm{PcSPC}$ & 16 \\
\hline & Pathumthani & PcPTC & 16 \\
\hline & Ayutthaya & PcAYC & 16 \\
\hline & Uthaithani & PcUTC & 7 \\
\hline & Songkhla & PcSKPT & 11 \\
\hline & Phangnga & PcPNPT & 7 \\
\hline \multirow[t]{4}{*}{ Pila ampullacea } & Don Maung & PaDMBK & 2 \\
\hline & Taling Chun & PaTCBK & 9 \\
\hline & Nakhonnayok & PaNNC & 8 \\
\hline & Nakhonpathom & PaNPC & 2 \\
\hline \multirow[t]{3}{*}{ Pila polita } & Sakhonnakhon & PoSNNE & 11 \\
\hline & Phrae & PoPRN & 10 \\
\hline & Phangnga & PoPNPT & 4 \\
\hline \multirow[t]{6}{*}{ Pila pesmei } & Khonkhen & PeKKNE & 9 \\
\hline & Sakhonnakhon & PeSNNE & 9 \\
\hline & Roiet & PeRENE & 8 \\
\hline & Kalasin & PeKSNE & 5 \\
\hline & Nakhonpathom & PeNPC & 7 \\
\hline & Ayutthaya & PeAYC & 9 \\
\hline \multirow[t]{3}{*}{ Pila angelica } & Songkhla & PanSKPT & 9 \\
\hline & Nakhonsithammarat & PanNSPT & 6 \\
\hline & Phangnga & PanPNPT & 10 \\
\hline
\end{tabular}

Abbreviations: Pc, Pomacea canaliculata; $\mathrm{Pa}$, P. ampullacea; Po, P. polita; Pe, P. pesmei; Pan, $P$. angelica $; \mathrm{N}=$ north, $\mathrm{NE}$, northeast; $\mathrm{C}=\mathrm{Central}$ region; $\mathrm{PT}$, peninsular Thailand

\section{DNA extraction}

Total DNA was extracted from a piece of the foot tissue of each snail using a phenol-chloroformproteinase K method (Winnepenninckx et al., 1993). DNA concentration was spectophotometrically determined and further adjusted by a mini-gel method (Maniatis et al., 1982). DNA was stored at $4^{\circ} \mathrm{C}$ until required. 


\section{Randomly amplified polymorphic DNA (RAPD) analysis and agarose gel electrophoresis}

Fifty decanucleotide primers were screened for the amplification success against a single individual of each species. RAPD-PCR was carried out in a $25 \mu \mathrm{l}$ reaction volume containing 10 mM Tris- $\mathrm{HCl}$, pH 8.8, $50 \mathrm{mM}$ KCI, Triton X-100, $2 \mathrm{mM} \mathrm{0.1 \%} \mathrm{mgCl}_{2}, 100 \mathrm{mM}$ of each dNTP, $0.4 \mu \mathrm{M}$ of each primer, 1 unit of DyNAzyme TM II DNA Polymerase (Finnzymes) and $25 \mathrm{ng}$ of DNA template. PCR was performed in a thermal cycler (Omnigene, Hybaid) for 40 cycles including denaturation at $94^{\circ} \mathrm{C}$ for 10 seconds, annealing at $36^{\circ} \mathrm{C}$ for 30 seconds and extension at $72^{\circ} \mathrm{C}$ for 90 seconds. The final extension was performed at $72^{\circ} \mathrm{C}$ for 5 minutes. Three primers (OPA07, OPB10 and UBC122) were chosen for population genetic studies of apple snails.

RAPD analysis using OPA07 and OPB10 was carried out using the conditions described above whereas amplification using UBC122 were performed for 35 cycles where denaturation and annealing steps were extended to 45 seconds and 60 seconds, respectively. The amplification products were electrophoretically analyzed through $1.6 \%$ agarose gels and visualized under a transilluminator after ethidium bromide staining (Maniatis et al., 1982).

\section{Data analysis}

Each RAPD fragment is treated as an independent character. Sizes of RAPD bands were estimated by comparing with a $100 \mathrm{bp}$ ladder and recorded in a binary matrix to represent the absence (0) or presence (1) of a particular band.

The similarity index between individuals was calculated by $S_{x y}=2 n_{x y} / n_{x}+n_{y}$, where $n_{x}$ and $\mathrm{n}_{\mathrm{y}}$ represent the number of RAPD bands in individuals $\mathrm{x}$ and $\mathrm{y}$, and $\mathrm{n}_{\mathrm{xy}}$ represents the number of shared bands between individuals (Nei and Li, 1979).

Within samples similarity $\left(\mathrm{S}_{\mathrm{i}}\right)$ is calculated as the average of $\mathrm{S}_{\mathrm{xy}}$ across all possible comparisons between individuals within a geographic sample.

Between sample similarity corrected by within sample similarity $\left(S_{i}\right.$ and $S_{j}$ of geographic samples $\mathrm{i}$ and $\mathrm{j}$, respectively) is also calculated between pairs of individuals across samples $\mathrm{i}$ and $\mathrm{j}$ using the equation; $S^{\prime}{ }_{i j}=1+S_{i j}-\left(S_{i}\right.$ and $\left.S_{j}\right) / 2$. Genetic distance between paired samples was then calculated as D' ${ }_{i j}=1-S_{i j}^{\prime}($ Lynch, 1990).

Unrooted Neighbor-joining trees (Saitou and Nei, 1987) were constructed from genetic distances between pairs of geographic samples within Pomacea canaliculata and between apple snail species using Neighbor in PHYLIP 3.56c (Felsenstein, 1993).

\section{Development of a Pila-specific SCAR marker}

Candidate species-specific RAPD markers successfully amplified in $>95 \%$ of the target species (Fig. 2 and Table 5) were excised from the gel and re-amplified. The eluted product was separately ligated to pGEM-T Easy vector (Promega) overnight at $4^{\circ} \mathrm{C}$ before transformed into E. coli XL1-BLUE (Maniatis et al., 1982). Sizes of inserts were verified by 
A

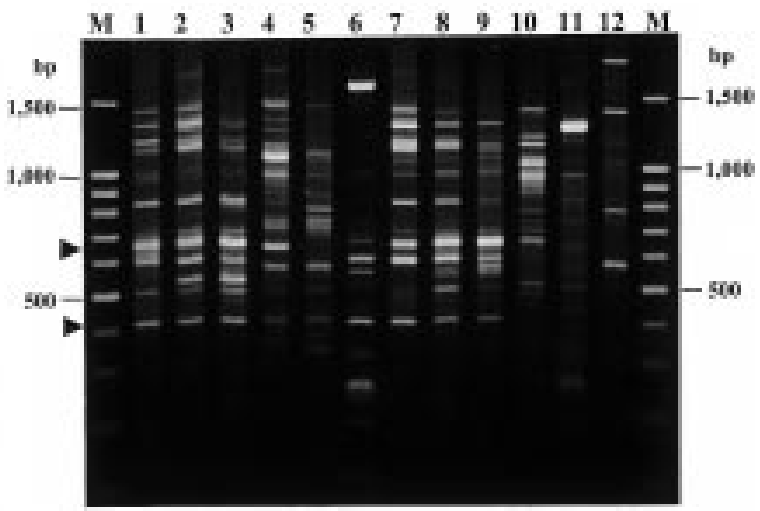

B

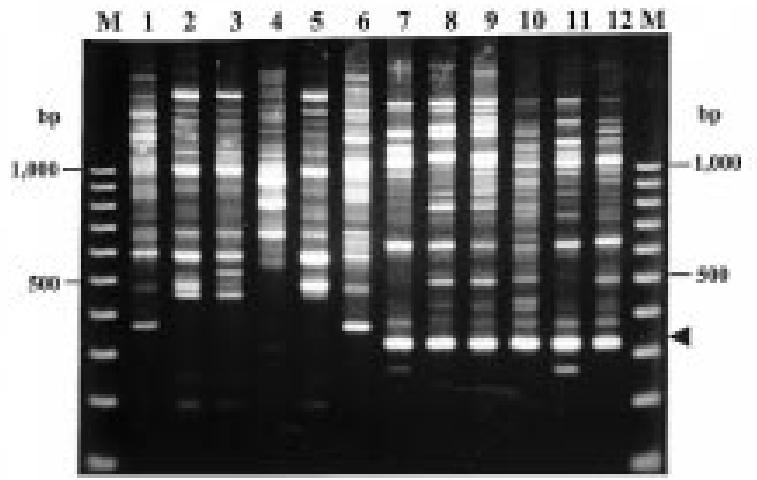

C

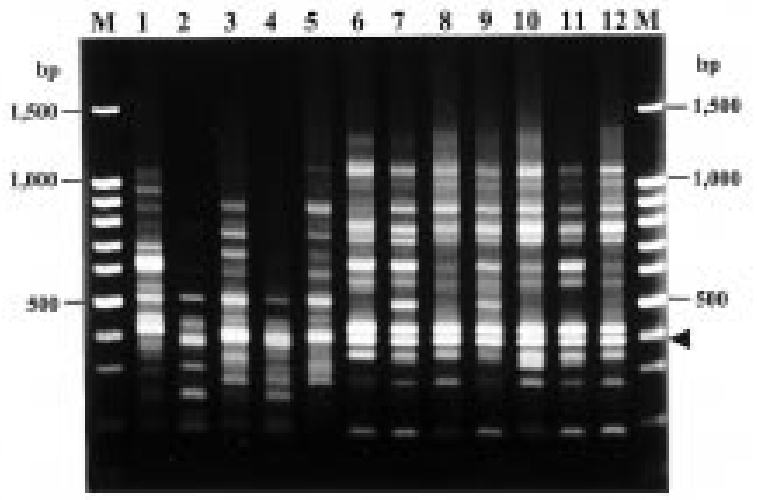

Figure 2 : Agarose gel elctrophorresis illustrating a candidate species-specific marker for P. ampullacea (640 bp, panel A lanes 1-3 and 7-9) and Pila apple snails (430 bp, panel A lanes 1-9 where lanes 4-6 and 10-12 were P. pesmei and Pomacea canaliculata, respectively), Pomacea canaliculata (340 bp, panel B lanes 7-12 where lanes 1-6 were Pila apple snails) and P. angelica (380 bp, panel C lanes 6-12 where lanes 1 and 2-5 were Pomacea canaliculata and P. pesmei, respectively). Arrowheads indicated species-diagnostic RAPD markers described in Table 5. 
colony PCR using primers pUC1 (5'-TCCGGCTCGTATGTTGTGTGGA-3') and pUC2 (5'-GTGCTGCAAGGCGATTAAGTTGG-3'). Recombinant clones representing those inserts were unidirectional sequenced using an automated sequencer (LI-COR 4100). Nucleotide sequences were blasted against data in the GenBank using BlastN and BlastX. Significant matching was considered when the probability (E) value was $<10^{-4}$.

Four pairs of primers (Table 6 ) were designed using OLIGO 4.0 and tested against representative individuals of the target $(N=10)$ and non-target species $(N=2-5)$. Primers pKURAPDPA2F/R were further tested against 163 individuals of native snail species $(N=38,27,30$ and 68 for P. ampullacea, P. polita, P. angelica and P. pesmei, respectively) and 30 individuals of Pomacea canaliculata.

PCR was performed in a $25 \mu \mathrm{l}$ reaction volume containing $10 \mathrm{mM}$ Tris- $\mathrm{HCl}, \mathrm{pH} 8.8,50 \mathrm{mM}$ $\mathrm{KCl}, 0.1 \%$ Triton $\mathrm{X}-100,2.0 \mathrm{mM} \mathrm{MgCl} 2,100 \mu \mathrm{M}$ of each dNTP, $0.2 \mu \mathrm{M}$ of each primer, 1.0 unit of DyNAzyme ${ }^{\mathrm{TM}}$ II DNA Polymerase (Finnzymes) and $25 \mathrm{ng}$ of DNA template. Amplification was composed of predenaturation at $94^{\circ} \mathrm{C}$ for 3 minutes followed by 10 cycles of $94^{\circ} \mathrm{C}$ for 30 seconds, annealing at $65^{\circ} \mathrm{C}-1^{\circ} \mathrm{C}$ per cycle for 1 minute and extension at $72^{\circ} \mathrm{C}$ for 1 minute and additional 35 cycles at the annealing temperature of $53^{\circ} \mathrm{C}$. The final extension was performed at $72^{\circ} \mathrm{C}$ for 7 minutes. The resulting product was electrophoretically analyzed through $1.8 \%$ agarose gels.

\section{RESULTS}

\section{Genetic diversity and differentiation of apple snails in Thailand revealed by RAPD analysis}

Among 50 investigated primers, 28 primers could amplify genomic DNA of both Pila and Pomacea canaliculata successfully. Three primers (OPA07, OPB10 and UBC122) exhibiting reproducible and easy scoring results were selected for analysis of genetic diversity and identification of molecular markers of apple snails in Thailand (Fig 2).

High genetic polymorphism was observed in all snail species. A total of 202 RAPD fragments ranging from $180 \mathrm{bp}$ and $1500 \mathrm{bp}$ in length were generated (Table 2). The number of scored

Table 2: Sequences of RAPD primers, sizes and number of amplified bands and the percentage of polymorphic bands resulted from RAPD analysis of the introduced (Pomacea canaliculata) and native ( $P$. ampulacea, $P$. angelica, $P$. pesmei and $P$. polita) apple snails in Thailand using OPA07, POB10 and UBC122

\begin{tabular}{llccc}
\hline Primers & Sequences & $\begin{array}{c}\text { Size-range } \\
\text { (bp) }\end{array}$ & $\begin{array}{c}\text { No. of RAPD } \\
\text { bands }\end{array}$ & $\begin{array}{c}\text { Polymorphic } \\
\text { band (\%) }\end{array}$ \\
\hline OPA07 & GAAACGGGTG & $190-1500$ & 67 & 100 \\
OPB10 & CTGCTGGGAC & $200-1500$ & 71 & 100 \\
UBC122 & GTAGACGAGC & $180-1500$ & 64 & 100 \\
Overall & & $\mathbf{1 8 0 - 1 5 0 0}$ & $\mathbf{2 0 2}$ & $\mathbf{1 0 0}$ \\
\hline
\end{tabular}


Table 3 : Total number of bands, percentage of polymorphic and monomorphic bands of each apple snail revealed by RAPD analysis using primers OPAO7, OPB10 and UBC122

\begin{tabular}{|c|c|c|c|c|c|c|c|c|c|}
\hline \multirow[t]{2}{*}{$\begin{array}{c}\text { Primer } \\
\text { No. }\end{array}$} & \multicolumn{3}{|c|}{$\begin{array}{l}\text { Pomacea canaliculata } \\
\qquad(N=136)\end{array}$} & \multicolumn{3}{|c|}{$\begin{array}{l}\text { P. ampullacea } \\
(N=21)\end{array}$} & \multicolumn{3}{|c|}{$\begin{array}{l}P . \text { angelica } \\
(N=25)\end{array}$} \\
\hline & $\begin{array}{c}\text { No. } \\
\text { of } \\
\text { bands }\end{array}$ & $\begin{array}{c}\text { No. of } \\
\text { polymorphic } \\
\text { bands }\end{array}$ & $\begin{array}{c}\text { No. of } \\
\text { monomorphic } \\
\text { bands }\end{array}$ & $\begin{array}{c}\text { No. } \\
\text { of } \\
\text { bands }\end{array}$ & $\begin{array}{c}\text { No. of } \\
\text { polymorphic } \\
\text { bands }\end{array}$ & $\begin{array}{l}\text { No. of } \\
\text { monomorphic } \\
\text { bands }\end{array}$ & $\begin{array}{c}\text { No. } \\
\text { of } \\
\text { bands }\end{array}$ & $\begin{array}{c}\text { No. of } \\
\text { polymorphic } \\
\text { bands }\end{array}$ & $\begin{array}{c}\text { No. of } \\
\text { monomorphic } \\
\text { bands }\end{array}$ \\
\hline OPA07 & 35 & 35 & 0 & 29 & 32 & 1 & 27 & 25 & 2 \\
\hline OPB10 & 28 & 28 & 0 & 33 & 32 & 0 & 24 & 23 & 1 \\
\hline UBC122 & 25 & 24 & 1 & 30 & 21 & 3 & 26 & 22 & 4 \\
\hline Total & 88 & $87(98.86 \%)$ & $1(1.36 \%)$ & 92 & $87(94.56 \%)$ & $5(5.43 \%)$ & 77 & $70(90.91 \%)$ & $7(9.09 \%)$ \\
\hline
\end{tabular}

\begin{tabular}{|c|c|c|c|c|c|c|}
\hline \multirow[t]{2}{*}{$\begin{array}{c}\text { Primer } \\
\text { No. }\end{array}$} & \multicolumn{3}{|c|}{$\begin{array}{c}P . \text { pesmei } \\
(N=47)\end{array}$} & \multicolumn{3}{|c|}{$\begin{array}{l}P . \text { polita } \\
(N=25)\end{array}$} \\
\hline & $\begin{array}{c}\text { No. } \\
\text { of } \\
\text { bands }\end{array}$ & $\begin{array}{c}\text { No. of } \\
\text { polymorphic } \\
\text { bands }\end{array}$ & $\begin{array}{c}\text { No. of } \\
\text { monomorphic } \\
\text { bands }\end{array}$ & $\begin{array}{c}\text { No. } \\
\text { of } \\
\text { bands }\end{array}$ & $\begin{array}{l}\text { No. of } \\
\text { polymorphic } \\
\text { bands }\end{array}$ & $\begin{array}{c}\text { No. of } \\
\text { monomorphic } \\
\text { bands }\end{array}$ \\
\hline OPA07 & 30 & 29 & 1 & 33 & 32 & 1 \\
\hline OPB10 & 31 & 29 & 2 & 32 & 32 & 0 \\
\hline UBC122 & 37 & 37 & 0 & 24 & 21 & 3 \\
\hline Total & 98 & $95(96.94 \%)$ & $3(3.06 \%)$ & 89 & $85(95.51 \%)$ & $4(4.49 \%)$ \\
\hline
\end{tabular}


bands across all investigated species was 67, 71 and 64 bands for primers OPA07, OPB10 and UBC122, respectively. All of these were polymorphic (found in less than 95\% of overall investigated specimens) indicating extremely high genetic diversity levels of apple snails (Table 3).

The average number of bands per primer was 29.33 for Pomacea canaliculata and 30.67, 25.67, 32.67 and 29.67 for $P$. ampullacea, $P$. angelica, $P$. pesmei and $P$. polita, respectively. The percentage of polymorphic bands of respective species was $98.86 \%, 94.56 \%, 90.91 \%$, 96.94\% and $95.51 \%$ (Table 3) indicating that genetic diversity of the introduced and native apple snails with the exception of $P$. angelica was comparable. While $P$. angelica exhibited the highest level of the similarity index within species $(0.7184 \pm 0.0385), P$. pesmei showed the lowest within species similarity index $(0.5909 \pm 0.0232)$.

The average genetic distance between geographic samples within species across all primers of Pomacea canaliculata, P. ampullacea, P. angelica, P. pesmei, and P. poilta ranged from $0.0213-0.0543,0.0378-0.1622,0.0546-0.2495,0.0003-0.1056$ and $0.0174-0.0948$, respectively. The average genetic distances between different species of apple snails was 0.2527 (P. polita-P. pesmei) - 0.3540 (P. polita-Pomacea canaliculata) (Table 4).

Table 4: Average genetic distances $\left(D_{i j}{ }_{i j}\right.$, below diagonal) and similarity indices $\left(S_{i j}^{\prime}\right.$, above Subscripts diagonal) between species of apple snails in Thailand based on RAPD analysis using OPAO7, OPB 10 and UBC122

\begin{tabular}{lccccc}
\hline & $\begin{array}{c}\text { Pomacea } \\
\text { canaliculata }\end{array}$ & P. ampullacea & P. angelica & P. pesmei & P. polita \\
\hline $\begin{array}{l}\text { Pomacea } \\
\text { canaliculata }\end{array}$ & - & 0.6629 & 0.6695 & 0.6765 & 0.6460 \\
$\begin{array}{l}\text { P. ampullacea } \\
\text { P. angelica }\end{array}$ & 0.3372 & - & 0.6488 & 0.7142 & 0.6505 \\
P. pesmei & 0.3305 & 0.3512 & - & 0.6762 & 0.6558 \\
P. polita & 0.3235 & 0.2859 & 0.3239 & - & 0.7473 \\
& 0.3540 & 0.3495 & 0.3442 & 0.2527 & - \\
\hline
\end{tabular}

A neighbor-joining (NJ) tree constructed from the average RAPD genetic distance between pairs of geographic samples within Pomacea canaliculata did not show phylogeography in this species (Fig. 3) but divided the introduced Pomacea canaliculata into 4 closely related groups; I (PcSPC, PcPTC, PcAYC and PcTCBK), II (PcSNNE, PcPNPT and PcNNC), III (PcUTC, PcCMN, PcNPC and PcKUBK) and IV (PcPRN, PcKKNE and PcSKPT) disregarding their geographic origins. At the interspecific levels, a neighbor-joining tree indicated large genetic differences between apple snail species (Fig. 4). 
AJSTD Vol. 20 Issue $3 \& 4$

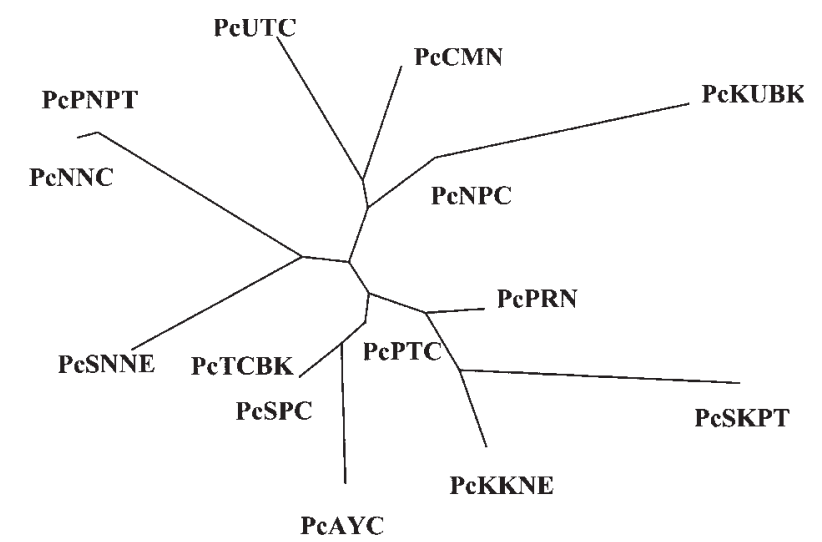

0,01

Figure 3: A neighbor-joining tree illustrating genetic relationships of Pomacea canaliculata in Thailand based on RAPD genetic distance between pairs of geographic samples using primers OPAO7, OPB10 and UBC122.

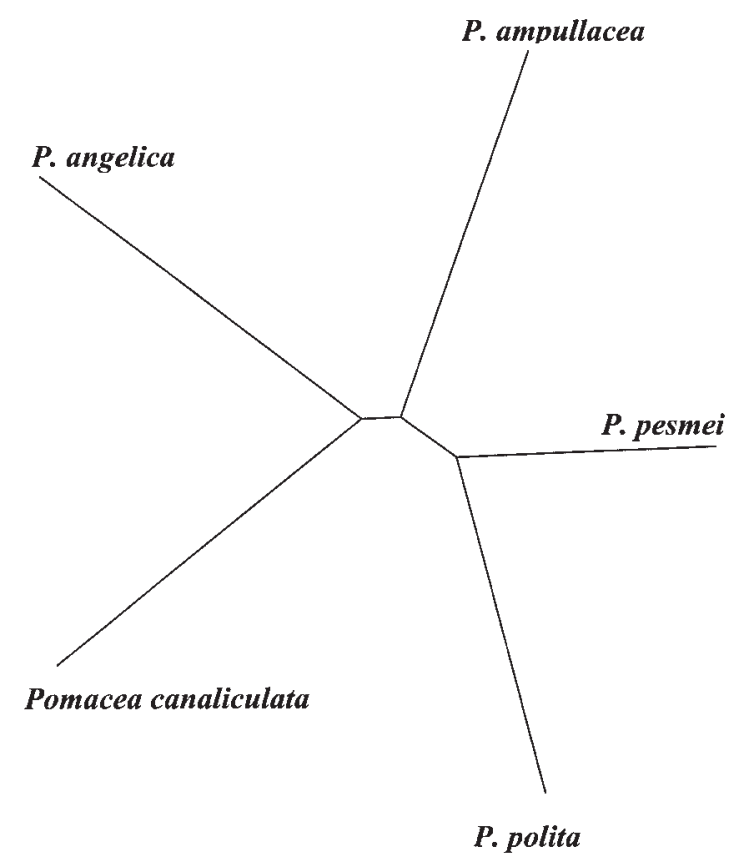

0.1

Figure 4: A neighbor-joining tree illustrating genetic relationships of Pomacea canaliculata, $P$. ampullacea, $P$. angelica, P. pesmei and P. polita based on the average RAPD genetic distance between apple snail species using primers OPA07, OPB10 and UBC122. 
Development of a sequence-characterized amplified region (SCAR) marker for detection of Pila apple snails in Thailand

Although high polymorphic levels were observed from RAPD analysis, candidate genus- and/ or species-specific RAPD markers observed in greater than $95.0 \%$ of the target apple snail species were also found (Fig. 2 and Table 5). These promising RAPD bands were cloned and further characterized.

Two different recombinant clones from $640 \mathrm{bp}$ (pKURAPDPA1 and pKURAPDPA2) and 340 bp (pKURAPDPC1 and pKURAPDPC2) and a single clone from 380 bp (pKURAPDPAN1)

Table 5 : Candidate species-specific RAPD markers of apple snails in Thailand revealed by RAPD analysis

\begin{tabular}{lllc}
\hline Primer & RAPD marker & \multicolumn{1}{c}{ Species/Genus } & $\begin{array}{c}\text { Specificity in target } \\
\text { species (\%) }\end{array}$ \\
\hline OPB10 & $340 \mathrm{bp}$ & Pomacea canaliculata & 95.0 \\
OPA07 & $640 \mathrm{bp}$ & P. ampullacea & 100 \\
UBC122 & $380 \mathrm{bp}$ & P. angelica & 100 \\
OPA07 & $430 \mathrm{bp}$ & Pila & 96.5 \\
\hline
\end{tabular}

Table 6 : Sequences of locus-specific primers designed from recombinant clones possessing a species-specific RAPD fragment of Pomacea canaliculata, P. ampullacea and $P$. angelica and Pila snails

\begin{tabular}{lll}
\hline \multicolumn{1}{c}{ Clone } & \multicolumn{1}{c}{ Primer sequence } & \multicolumn{1}{c}{$\begin{array}{c}\text { Amplification } \\
\text { results }\end{array}$} \\
\hline pKURAPDPC1 $^{\text {a }}$ & ND & ND \\
PKURAPDPC2 $^{\text {a }}$ & ND & ND \\
pKURAPDPA1 & F: 5'-CCC GCC GTG ACA ACA GTA AG-3' & 52.63\% in P. \\
(a 640 bp insert) & R: 5'-AGA TGA ACT GAG CAG CAG AAA CA-3' & $\begin{array}{l}\text { ampullacea but } \\
\text { not in other }\end{array}$ \\
& & species \\
pKURAPDPAN1 & F: 5'-TCT TTT CTT GTA TTA CTG TGC TAT G-3' & - \\
(a 380 bp insert) & R: 5'-GCC TTA CCA GGG TTA GGA TTT A-3' & \\
pKURAPDPI1 & F: 5'-CAG TCT CAG GAT GGG ATT CAG G-3' & - \\
(a 430 bp insert) & R: 5'-TCA GGG TCG TGT TCC GCT TT-3' & 95\% in Pila apple \\
pKURAPDPA2 & F: 5'-CCG TGC AAA AGG CAA ACT GAA-3' & snails but not in \\
(a 640 bp insert) & R: 5'-AGG GAA CGA TGG GTT GGG ATT-A 3' & Pomacea \\
& & canaliculata \\
\hline
\end{tabular}

a SCAR markers were not developed from these sequences because a simple and reliable PCR-based method for identification of Pomacea canaliculata was already developed based on 16S rDNA polymorphism (Thaewnon-ngiw, 2003).

${ }^{b}$ Subsequently, pKURAPDPA2-F/R were called as pKUSCARPILA-F/R.

-, amplification was not successful; ND, not determined. 


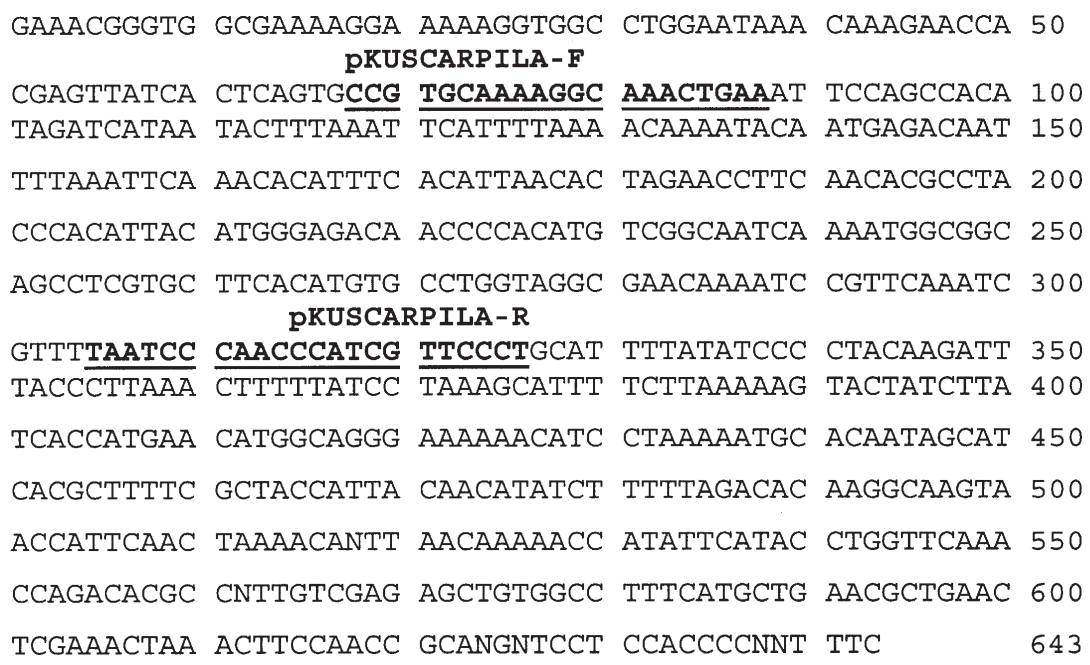

Figure 5: Nucleotide sequences of pKUSCARPILA (formerly called pKURAPDPA2). The locations and sequences of a Pila-specific forward primer (pKUSCARPILA-F) and those complementary to a reverse primer ( $p K U S C A R P I L A-R)$ are labeled in boldface and underlined.

and $340 \mathrm{bp}$ (pKURAPDPI1) inserts were unidirectional sequenced. Results from blasted analysis did not show significant matching of these sequences with any sequence in the GenBank (E-value > 0.0001). Therefore, these RAPD fragments were regarded as unknown sequences.

Primers pKURAPDPAN1-F/R and pKURAPDPI1-F/R did not provide the products even though amplification conditions were further adjusted (e.g. thermal profiles, $\mathrm{MgCl}_{2}$ concentration). A preliminary result using pKURAPDPA1 primers revealed $100 \%$ successful amplification in $P$. ampullacea $(N=10)$. Nevertheless, only $52.63 \%$ of overall $P$. ampullacea specimens $(N=38)$ were successfully amplified by this primer set (Table 6).

Surprisingly, pKURAPDPA2-F/R (hereafter called pKUSCARPILA primers) did not only amplify $P$. ampullacea DNA (the amplification success $=35 / 38$ individuals) but also provided the expected amplification product in $P$. angelica $(30 / 30)$, P. pesmei $(65 / 68)$ and $P$. polita $(24 / 27)$ but not in Pomacea canaliculata $(N=30)$. The amplification success was accounted for $95.09 \%$ (155/163) across overall investigated Pila apple snails (Fig. 6).

\section{DISCUSSION}

\section{Genetic diversity of apple snails in Thailand}

Using RAPD analysis, genetic diversity of Pomacea and Pila apple snails in Thailand was elucidated. Molecular genetic markers for differentiation of Pila and Pomacea apple snails were 


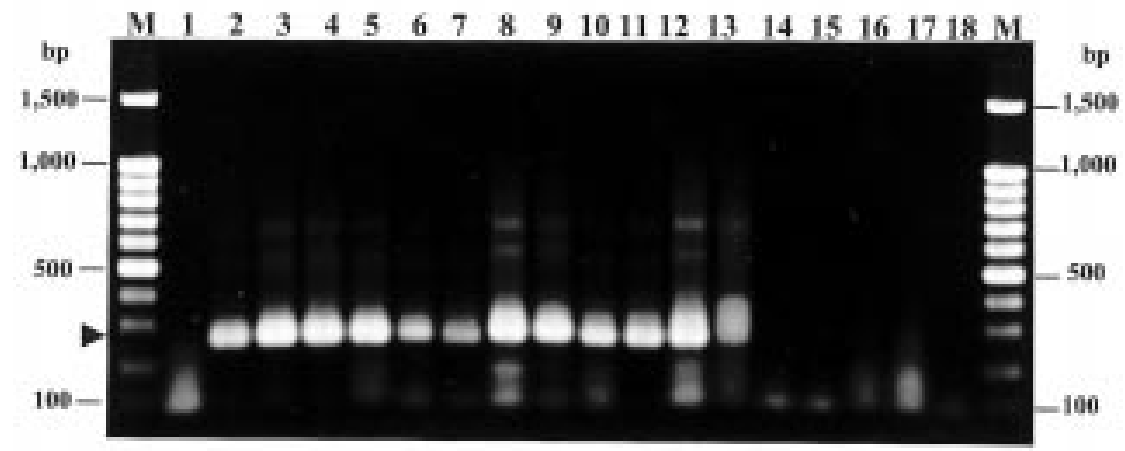

Figture 6 : Agarose gel electrophoresis showing specificity of $p K U S C A R P I L A-F / R$ primers against genomic DNA of Pila apple snails (lanes 2 - 13) and Pomacea canaliculata (lanes 14 - 18). Arrowheads indicate a 259 bp PCR product. Lane 1 was a negative control (without DNA template). A 100 bp ladder (lanes M) was used as the DNA marker.

identified. Simplification for detection of Pila apple snails by a PCR-amplified SCAR marker was successfully developed.

All scored RAPD bands generated by each primer across overall species were polymorphic. The average number of polymorphic bands of each species was nearly identical where a lower level of polymorphic bands (90.91\%) was observed in P. angelica. This suggested the potential of RAPD analysis for determination of inter- and intraspecific genetic differences of apple snails in Thailand. Similar circumstances on high genetic polymorphism detected by RAPD analysis across investigated species were also found in the mud crabs; Scylla serrata, S. oceanica and S. tranquebarica (Klinbunga et al., 2000) and the cupped oysters of genera Saccostrea; S. cucullata, and S. forskali and Striostrea; Striostrea (Parastriostrea) mytiloides (Klinbunga et al., 2001).

Although limited numbers of native apple snails were included in our experiments, specimens were collected from major parts of their geographic ranges and should have represented the gene pool of a particular species. We did not include $P$. gracilis in the present study because it was not found during sampling collection even though $P$. gracilis was previously reported to be common in the further south of Phangnga (Keawjam, 1986).

Recently, genetic diversity and molecular diagnostic markers of Pomacea canaliculata and four native apple snails ( $P$. ampullacea, $P$. angelica, P. pesmei and P. polita) in Thailand were also studied by PCR-RFLP of cytochrome oxidase subunit I, COI (Thaewnon-ngiw, 2003). Twentyone mitochondrial composite haplotypes showing non-overlapped distribution between species were found. Geographic heterogeneity analysis indicated significant genetic differences among species $(\mathrm{P}<0.0001)$ and within P. pesmei $(\mathrm{P}<0.0001)$ and P. angelica $(\mathrm{P}<0.0004)$. Nevertheless, a panmictic gene pool was observed in Pomacea canaliculata $(\mathrm{P}>0.05), P$. ampullacea $(\mathrm{P}=0.0824-1.000)$ and $P$. polita $(\mathrm{P}=1.0000)$. Neighbor-joining trees constructed from divergence 
between pairs of composite haplotypes, geographic samples and species revealed clear differentiation among snail species.

Notably, genetic diversity resulted from RAPD analysis was contradictory to that from PCRRFLP of COI (Thaewnon-ngiw, 2003). Restriction analysis of COI revealed a lack of genetic polymorphism in $P$. polita but the present study indicated the high level of polymorphism in that species. This should have resulted from the female founder effects in $P$. polita. Moreover, the former approach revealed that $P$. angelica exhibited the highest level among investigated species. Nevertheless, this species showed the lowest diversity level when analyzed by RAPD-PCR. This should have resulted from limited sample sizes of native apple snails in the present study.

Contradictory results on genetic diversity levels of the same investigated samples analyzed by different molecular markers have been previously reported. Sihanuntavong et al. (1999) and Sittipraneed et al. (2001a) examined genetic diversity and population differentiation of the honey bee (Apis cerana) in Thailand by restriction analysis of small subunit (s) rDNA, large subunit (lr) rDNA and the intergenic COI-COII with Dra I. Low haplotype and nucleotide diversity levels were found in the north-to-central, peninsular Thailand and Phuket Island populations while the highest diversity was observed in bees from Samui Island. Geographic heterogeneity analysis and $F_{S T}$ estimate differentiated A. cerana in Thailand into 3 populations including northern Thailand (A), Peninsular Thailand (B) and Samui Island (C). Using microsatellite analysis, high levels of heterozygosity were observed in bees from the north-tocentral (north, north-east and central region) and peninsular Thailand $\left(H_{e}=0.52-0.59\right)$ but limited heterozygosity was found in the Samui Island sample $\left(H_{e}=0.28\right)$. The north-east sample could be further differentiated from the north and the central regions (Sittipraneed et al., 2001b).

On the basis of RAPD analysis, genetic distance between geographically different samples of Pomacea canaliculata was small (-0.3021 - 0.0543) implying low degrees of genetic differentiation in this species. In addition, phylogeny of Pomacea canaliculata did not illustrate phylogeography in this species but rather reflected effects of multiple introduction of Pomacea canaliculata from different geographic origins to Thailand. The lack of geographic heterogeneity of Pomacea canaliculata in Thailand analyzed by COI polymorphism (Thaewnon-ngiw, 2003) supported results from RAPD analysis in this study.

Differentiation between juvenile Pomacea canaliculata and Pila apple snails based on external morphology is difficult. Moreover, it has been suspected that intergeneric (between Pomacea canaliculata and each Pila species) and intrageneric (between species within the genus Pila) hybridization and gene introgression of apple snails in Thailand may be occurred. Phylogenetic analysis based on RAPD analysis (this study) and restriction analysis of COI (Thaewnon-ngiw, 2003) unambiguously suggested that the occurrence of hybridization and introgression of apple snails in Thailand at both inter- and intrageneric levels was unlikely.

Notably, some pairwise comparisons of genetic distance between Pomacea canaliculata and Pila apple snails were lower than those within the genus Pila implying that genetic distance estimated from RAPD analysis rapidly reached a plateau of divergence among these taxa. This may saturate phylogenetic data of apple snails in this study. Moreover, genetic diversity based 
on RAPD analysis relied entirely on sharing of RAPD-amplified fragments after electrophoresis. The possibility of comigration of RAPD fragments having similar sizes but different sequences cannot be excluded (Klinbunga et al., 2001). Therefore, homology of comigrating fragments should be further verified by Southern blotting hybridization.

\section{Pomacea canaliculata-specific RAPD and Pila-specific SCAR markers}

Several useful genetic markers were identified in this study. An intense 340 bp RAPD fragment was found in approximately $95.0 \%$ of overall investigated Pomacea canaliculata specimens $(N=136)$ and could be simply used as Pomacea canaliculata-diagnostic markers.

Although species-specific RAPD markers of apple snail allow direct examination of snail species, RAPD-PCR is sensitive to reaction conditions due to low reproducibility of this technique (Hadrys et al., 1992). Moreover, RAPD-PCR also requires good quality DNA template for reliable and consistent results which may not be possible for field specimens. This may significantly cause false negative results from positive specimens (Weising et al., 1995).

Concurrently, Thaewnon-ngiw et al., (2003) developed species-diagnostic markers of Pomacea canaliculata in Thailand. The 16S rDNA of representative individuals of each apple snail species were cloned and sequenced. Species-specific PCR for Pomacea canaliculata was successfully developed ( $N=131$ and 82 for the target and non-target species) with the sensitivity of detection approximately $50 \mathrm{pg}$ of the target DNA template. Amplification of genomic DNA (50 pg and $25 \mathrm{ng}$ ) isolated from the fertilized egg, and juveniles (1,7 and 15 days after hatching) of Pomacea canaliculata was also successful suggesting that discrimination of Pomacea canaliculata and Pila species could be carried out since the early stages of development.

Using an identical approach, candidate Pila-specific (430 bp from OPA07), P. ampullaceaspecific (640 bp from OPA07) and P. angelica-specific (380 bp from UBC122) RAPD fragments were cloned and sequenced. SCAR markers were then developed. Only, pKUSCARPILAF/R (formerly called pKURAPDPA2-F/R) primer pair provided specific amplification results in 95.09\% of Pila (P. ampullacea, P. angelica, P. pesmei and P. polita) but not in Pomacea canaliculata. This indicated the successful development of a specific SCAR marker for detection of Pila apple snails in Thailand. On the basis of the original data, a 640 bp RAPD band was $P$. ampullacea-specific. Therefore, Pila-specific nature of the derived SCAR marker may have explained by the occurrence of an alternative allele of this locus in $P$. angelica, $P$. pesmei and P. polita but complexity of RAPD patterns obviated the ability to identify that alternative RAPD band after gel electrophoresis.

RAPD-PCR is one of the potential approaches for identification of molecular genetic markers in various taxa (Hadrys et al., 1992; Stothard and Rolinson, 1996; Klinbunga et al., 2001 and 2002). In the present study, we used this technique to examine genetic diversity of apple snails in Thailand and to identify diagnostic RAPD and SCAR markers for Pomacea canaliculata and Pila apple snails, respectively. These markers could be used together for unambiguously discriminate the introduced and native apple snails in Thailand. 


\section{ACKNOWLEDGMENTS}

We thank the National Center for Genetic Engineering and Biotechnology (BIOTEC), National Science and Technology Development Agency (NSTDA) for providing facilities required by our experiments. Our sincere appreciation goes to Piti Amparyup for technical assistance.

\section{REFERENCES}

1. Brandt, R.A.M. (1974). The non-marine aquatic mollusca of Thailand. Archiv fur Molluskenkunde. 105: 1-423.

2. Carvolho, G.R. and Hauser, L. (1994). Molecular genetics and the stock concept in fisheries. Rev. Fish Biol. Fisheries 4: 326-350.

3. Felsenstein, J. (1993). Phylip (Phylogenetic Inference Package) version 3.5c. Distributed by the author. Department of Genetics, University of Washington, Seattle.

4. Hadrys, H., Balick, M. and Schierwater, B. (1992). Applications of random amplified polymorphic DNA (RAPD) in molecular ecology. Mol. Ecol. 1: 55-63.

5. Janyapeth, S. and Archawakom, T. (1999). Biology of the alien apple snails. In: Thai Ministry of Agriculture and Cooperatives: Conference Report on the Alien Apple Snail. Pailin Hotel, Phitsanulok, pp. 1.1-1.15.

6. Keawjam, R.S. (1986). The Apple snails of Thailand: distribution habitat and shell morphology. Malacol. Rev. 19: 61-81.

7. Keawjam, R.S. (1987). The Apple snails of Thailand: aspects of comparative anatomy. Malacol. Rev. 20: 69-89.

8. Keawjam, R.S. and Upatham, E.S. (1990). Shell morphology, reproductive anatomy and genetic patterns of three species of apple snails of the genus Pomacea in Thailand. $J$. Med. Appl. Malacol. 2: 45-57.

9. Klinbunga, S., Boonyapakdee, A. and Pratoomchat, B. (2000). Genetic diversity and species diagnostic markers of mud crabs (Genus Scylla) in eastern Thailand determined by RAPD analysis. Mar. Biotechnol. 2: 180-187.

10. Klinbunga, S., Ampayup, P, Tassanakajon, A., Jarayabhand, P. and Yoosukh, W. (2001). Genetic diversity and molecular markers of cupped oysters (Genera Crassostrea, Saccostrea and Striostrea) in Thailand revealed by Randomly Amplified Polymorphic DNA analysis. Mar. Biotechnol. 3: 133-144.

11. Klinbunga, S., Ampayup, P., Khamnamtong, N., Tassanakajon, A., Jarayabhand, P. and Yoosukh, W. (2002). Molecular genetic markers for taxonomy of oysters in Thailand. Fisheries Sci. 68 (suppl II) 1087-1090.

12. Lauhachinda, N., Duangswasdi, S. and Sidhi, S. (1988). South America golden apple snails (Pomacea canaliculata): the new pest of aquatic plants. In: $26^{\text {th }}$ Kasetsart University Conference Report, Kasetsart University, Bangkok, Thailand. pp. 108-115.

13. Lynch, M. (1990). The similarity index and DNA fingerprinting. Mol. Biol. Evol. 7: 478-484.

14. Maniatis, T., Fritsch, E.F. and Sambrook, J. (1982) Molecular Cloning: A Laboratory Manual. Cold Spring Habor Laboratory, Cold Spring Habor Press, New York 
15. Nei, M. and Li, W.H. (1979). Mathematical model for studying genetic variation in terms of restriction endonucleases. Proc. Natl. Acad. Sci. USA 76: 5269-5273.

16. Pain, T. (1972). The Ampullariidae, an historical survey. J. Conchol. 27: 453-462.

17. Saitou, N. and Nei, M. (1987). The neighbor-joining method: a new method for reconstructing phylogenetic trees. Mol. Biol. Evol. 4: 406-425.

18. Sihanuntavong, D., Sittipraneed, S. and Klinbunga, S. (1999) Mitochondrial DNA diversity and population structure of the honey bee, Apis cerana, in Thailand. J. Apic. Res. 38: 211-219.

19. Sittipraneed, S., Laoaroon, S., Klinbunga, S. and Wongsiri, S. (2001a) Genetic differentiation of the honey bee (Apis cerana) in Thailand: evidence from microsatellite polymorphism. J. Apic. Res. 40: 9-16.

20. Sittipraneed, S., Sihanuntavong, D. and Klinbunga, S. (2001b) Genetic differentiation of the honey bee (Apis cerana) in Thailand revealed by polymorphism of a large subunit of mitochondria ribosomal DNA. Insectes soc. 48: 266-272.

21. Stothard, J. R. and Rollinson, D. (1996). An evaluation of random amplified polymorphic DNA (RAPD) for the identification and phylogeny of freshwater snails of the genus Bulinus (Gastropoda : Planorbidae). J. Moll. Stud. 62: 165-176.

22. Thaewnon-ngiw, B. (2003): Species diversity and molecular markers of alien apple snails (Pomacea sp.) and native apple snails (Pila sp.) in Thailand. PhD Thesis, Interdisciplinary Graduate Program, Kasetsart University. 226 pp.

23. Weising, K., Hybom, H., Wolff, K. and Meyer, W. (1995). DNA Fingerprinting in Plants and Fungi. CRC Press, Boca Raton, FL.

24. Welsh, J. and McClellland, M. (1990). Fingerprinting genome using PCR with arbitrary primers. Nucleic Acids Res. 18: 7213-7218.

25. Williams, J.G.K., Kubelik, A.R., Lipak, K.J., Rafalski, J.A. and Tingey, S.V. (1990). DNA polymorphisms amplified by arbitrary primers are useful as genetic markers. Nucleic Acids Res. 18: 6531-6535.

26. Winnepenninckx, B., Backeljau, T. and De Wachter, R. (1993). Extraction of high molecular weight DNA from molluscs. TIG. 9: 407. 